\title{
PENERAPAN PERMAINAN EDUKATIF MEDIA BERGAMBAR
}

\author{
Nunuk Setiyowati \\ Raudhatul Atfhal 11 Siti Khadijah \\ e-mail: nunzahwa@gmail.com
}

Diterima: 17 November 2020I Direvisi: 19 November 2020 I Disetujui: 19 November 2020 (C)2020 Pendidikan Guru Raudhatul Atfhal Fakultas Agama Islam Universitas Islam Malang

\begin{abstract}
Play is the world of children. In play there is pleasure and satisfaction without coercion oriented to the process rather than the end result. Piaget (1962), suggested that learning while playing and playing while learning is an activity that must be presented so that children have readiness to enter further education. Educative games of pictorial media have an important role in developing all aspects of children's intelligence, because in educational play activities, pictorial games of children become active in moving and thinking so that new ideas and experiences that will be important for their growth and development will emerge. Group $A$ children are one of the times when children have to get a lot of positive stimulation in learning to develop their full potential, imagination and intelligence aspects so that they develop optimally. At this time it is often called a critical period or a golden age that whill not be repeated again. So that the role of parent, teacher and the environment becomes the main pillar for children's growht and development, so that children grow intro tough generations who excel and are ready to face every challenge and all the changing times.
\end{abstract}

Kata Kunci: media edukatif, media bergambar, anak kelompok $A$

\section{A. Pendahuluan}

Anak usia dini adalah sosok individu atau subjek pelaku kegiatan yang sedang menjalani suatu proses perkembangan dengan sangat pesat dan fundamental bagi kehidupan selanjutnya (Sujiono, 2009). Proses pertumbuhan dan perkembangan pada berbagai aspek mengalami masa yang gemilang dan siap untuk dikembangkan, sehingga disebut dengan masa golden age (Sulyandari, 2019). Pendapat tersebut sejalan dengan prinsip periode otak menyerap, karena pada masa tersebut perkembangan anak-anak siap diisi dan dikembangkan oleh berbagai hal yang bermakna (Montessori, 2013). Dewi, (2019) mengungkapkan, potensi dalam diri anak berkaitan dengan setiap aspek perkembangan yang dibawa sejak dalam kandungan. Oleh karena itu berbagai rangsangan dan pembiasaan baik harus diberikan kepada anak usia dini oleh orang-orang dan

This work is licensed under Creative Commons Attribution Non Commercial 4.0 International License Available online on: http://riset.unisma.ac.id/index.php/fai/index 
lingkungan yang ada disekitar anak usia dini, agar anak usia dini mampu melalui setiap tahap tumbuh kembangnya dengan baik. Anak berkembang dan belajar dari lingkungannya dan selalu mengalami perubahan, Semiawan (dalam Sujiono, 2009).

Bagi anak bermain adalah kegiatan serius namun mengasyikkan, melalui bermain semua aspek perkembangan dapat ditingkatkan. Menurut Anderson (2010), bermain dibutuhkan karena dapat menstimulus pertumbuhan anak diantaranya adalah menstimulus koneksi sel-sel syaraf. Pendidikan anak usia dini adalah belajar sambil bermain, Semiawan (dalam Sujiono 2007). Bermain sebagaimana dinyatakan Sigmund Freud (1958) dalam Bermain dan Permainan Anak Universitas Terbuka (2015) sangat bermanfaat sebagai terapi, dalam hal ini fungsi permainan edukatif media bergambar mempunyai peranan maksimal dalam mengatasi suasana pembelajaran yang kurang menyenangkan (monoton). Wolfinger (1994), mengungkapkan bahwa anak-anak akan lebih paham dengan cara bermain dan memanipulasi objek di sekitarnya serta bergerak aktif. Jadi media adalah alat yang digunakan untuk menyampaikan materi dan dapat merangsang peserta didik untuk bermain dan belajar.

Peran permainan edukatif media bergambar sebagai media pembelajaran pada anak didik kelompok A RA.11 Siti Khadijah Kota Batu diharapkan proses kegiatan belajar mengajar menjadi kondusif dan menyenangkan. Media menggambar, sangat memudahkan anak-anak untuk memahami apa yang dilihat, karena dengan media gamabr, anak-anak akan terasah kemampuan indrawinya, sedangkan diusia TK, kemampuan indrawi teklah berkembang dan siap untuk diberi stimulus, sehingga media gambar sangat cocok untuk diterapkan. (Sulyandari, 2017).

Berdasarkan penelitian terdahulu, sebelum adanya penerapan permainan edukatif media bergambar, pembelajaran masih belum bisa maksimal dilaksanakan. Hal ini dikarenakan oleh banyaknya peserta didik yang memilik bermacam potensi dan imajinasi, sehingga tidak semua terfasilitasi dengan baik. Hal ini menyebabkan minat belajar peserta didik menjadi rendah. Dari permasalahan tersebut, peneliti berupaya melakukan penelitian untuk mencari solusi mengatasi kondisi pembelajaran yang kurang maksimal. Selain itu, model pembelajaran sentra yang diterapkan di RA.11 Siti Khadijah Kota Batu sebagai model pembelajaran sangat menarik perhatian peneliti untuk menerapkan permainan edukatif media bergambar, dengan menggunakan model pembelajaran sentra penerapan permainan edukatif media bergambar akan menjadi mudah dan berlangsung dengan baik.

Ragam media bergambar yang peneliti sajikan dalam densitas sesuai tema pembelajaran terbukti dapat menarik minat peserta didik untuk menggunakannya, 
warna yang cerah dan gambar visual yang bervariasi pada media bergambar membuat imajinasi peserta didik berkembang pesat, sehingga aspek perkembangan kecerdasan terutama perkembangan motorik kasar dan halus peserta didik dalam merekronstruksi permainan edukatif media bergambar menjadikan suasana pembelajaran berlangsung sangat kondusif. Peserta didik menjadi lebih aktif dalam kegiatan pembelajaran dengan banyaknya pertanyaan sederhana yang diajukan kepada guru, daya imajinasi berkembang baik dengan banyaknya interaksi dan bermain peran bersama teman secara spontan dapat dilakukan oleh peserta didik.

Berdasarkan paparan tersebut, permasalahan yang dihadapi lembaga pendidikan RA.11 Siti Khadijah Kota Batu adalah banyaknya peserta didik kelompok A pada tahun ajaran 2019/2020 minat belajarnya rendah serta banyaknya peserta didik terpapar pengaruh penggunaan gawai yang belum bisa di atasi karena media pembelajaran yang monoton. Dari permasalahan diatas maka peneliti mengadakan penelitian dengan judul Penerapan Permainan Edukatif Media Bergambar Pada Anak Kelompok A Di RA.11 Siti Khadijah Kota Batu Peneliti mencoba melakukan upaya perbaikan pembelajaran yang bertujuan meminimalisir pengaruh penggunaan gawai dan meningkatkan minat belajar anak dengan menyajikan pembelajaran aktif menyenangkan dalam belajar sambil bermain dan bermain seraya belajar menggunakan media bergambar.

Dari konteks penelitian tersebut, maka fokus penelitian ini adalah; bagaimana upaya penerapan media bergambar dan peningkatan penyajian pembelajaran menyenangkan dengan bermain sambil belajar dan belajar sambil bermain untuk meningkatkan seluruh aspek perkembangan pada anak usia kelompok A di RA.11 Siti Khadijah Kota Batu. Sehingga tujuan penelitian yang akan dicapai adalah tersajinya pembelajaran menyenangkan dengan adanya penerapan permainan edukatif media bergambar yang menjadikan seluruh aspek perkembangan peserta didik berkembang dengan baik.

\section{B. Metode}

Penelitian ini menggunakan penelitian kualitatif deskripstif. Subyek penelitian adalah anak kelompok A sebanyak 38 anak. Teknik pengumpulan data menggunakan observasi, wawancara dan dokumentasi. Teknik analisis data menggunakan triangulasi. Adapun data yang dikumpulkan oleh peneliti yang nantinya digunakan sebagai instrumen penelitian, yaitu berupa data primer dan data sekunder. Data primer adalah data berupa keterangan langsung dari responden yang berkenaan dengan upaya guru dalam penyajian pembelajaran dan hasil belajar anak. Sedangkan data sekunder adalah data yang diperoleh dari 
dokumen-dokumen guru, data siswa dan model pembelajaran serta kurikulum pembelajaran di RA.11 Siti Khadijah.

\section{Hasil dan Pembahasan}

Penelitian ini merupakan penelitian deskriptif, sehingga hasil penelitian tentang penerapan permainan edukatif media bergambar pada anak usia kelompok A RA.11 Siti Khadijah dijabarkan secara narasi dan menyeluruh. Adapun hasil penelitian sebagai berikut; observasi kegiatan awal pembelajaran menggunakan permainan edukatif media bergambar pada hari senin, 13 Januari 2020 di sentra kreatifitas menunjukkan 3 anak yang tuntas dari jumlah 14 anak dalam 1 kelas. Kemudian pada observasi pembelajaran ke2 di sentra persiapan pada 29 Januari 2020 hari Rabu menunjukkan adanya peningkatan hasil belajar anak, yakni 5 anak tuntas dari jumlah 14 anak dalam 1 kelas, namun masih belum memenuhi indikator keberhasilan, sehingga peneliti melakukan penelitian ulang pembelajaran menggunakan media begambar ke3 dan dengan terus berinovasi dalam menyajikan permainan edukatif media bergambar diulang di sentra persiapan pada hari Rabu, 19 Pebruari 2020. Hasil belajar anak mengalami peningkatan melebihi indikator keberhasilan, ketuntasan belajar anak mencapai prosentase $100 \%$ dengan jumlah 14 anak tuntas dalam 1 kelas. Prosentase ini sudah memuaskan karena standart indikator keberhasilan anak adalah $75 \%$. Dengan demikian dapat diketahui bahwa penerapan permainan edukatif media bergambar yang disesuaikan dengan tema pembelajaran dan berbagai inovasi, kreativitas dari pendidik telah berhasil dan sudah mencapai hasil yang baik diatas rata-rata yang diharapkan.

Berdasarkan hal tersebut, tampak bahwa penerapan permainan edukatif media bergambar sangat berpengaruh pada keberhasilan belajar menyenangkan sambil bermain pada anak kelompok A. Semangat anak dalam belajar juga meningkat terbukti dengan banyaknya peserta didik yang menggunakan media bergambar memunculkan beberapa pertanyaan sederhana dan terjadinya interaksi yang baik sesama peserta didik dengan guru kelas. Berbagai permasalahan belajar anak juga mampu diselesaikan oleh peserta didik dengan adanya permainan edukatif media bergambar yang mampu membuat imajinasi peserta didik berkembang optimal.

Berdasarkan hasil penelitian menunjukkan bahwa penerapan permainan edukatif media bergambar anak kelompok A RA.11 Siti Khadijah Kota Batu menunjukkan peningkatan perbaikan dalam aktivitas belajar yang baik. Hal ini terbukti dengan adanya perubahan suasana pembelajaran yang tadinya monoton menjadi kondusif dan menyenangkan. Penerapan permaian edukatif media 
bergambar pada anak kelompok A RA.11 Siti Khadijah Kota Batu juga merupakan salah satu aktivitas yang baik dalam pemberian rangsangan kepada peserta didik untuk mengembangkan semua potensi dan aspek perkembangan yang ada pada peserta didik.

Alat permainan yang mengandung unsur pendidikan dan dilakukan dalam aktifitas menyenangkan yang bersifat mendidik dan bermanfaat dengan menggunakan segala alat fisik yang menyajikan pesan serta merangsang anak usia dini untuk belajar (Santi, 2009: 69). Alat permainan edukatif untuk anak TK adalah alat yang sengaja dirancang secara khusus untuk meningkatkan aspek-aspek perkembangan anak. Peralatan permainan yang disediakan hendaknya dapat membantu meningkatkan semua aspek perkembangan anak dalam memperoleh keterampilan, kreativitas imajinasi dan memberikan pengetahuan/pengalaman baru bagi anak (Moeslichatoen, 2004).

Pendapat lain dalam menggunakan peralatan bermain berupa gambargambar yang berkaitan dengan materi pembelajaran yang bisa dilihat dan digunakan untuk belajar sambil bermain serta tidak mempunyai unsur audio atau suara. Menurut Sadiman (2003: 21), media bergambar berfungsi untuk menyampaikan pesan sekaligus sebagai media pembelajaran yang diberikan guru kepada siswanya. Media bergambar juga bisa membantu siswa untuk mengungkap informasi yang terkandung dalam masalah, sehingga hubungan antar komponen dalam masalah tersebut bisa terlihat dengan jelas dan dapat diselesaikan. Kegiatan pembelajaran dilakukan dengan menggunakan metode bermain sambil belajar dan belajar seraya bermain dalam upaya meminimalisir pengaruh penggunaan gawai. Penggunaan permainan edukatif berupa media bergambar pada saat pembelajaran menjadikan pembelajaran lebih bermakna, bervariasi dan menyenangkan. Dengan pembelajaran yang menyenangkan menjadikan anak-anak mudah memahami dan materi yang disampaikan oleh guru mudah diterima dengan baik oleh anak-anak.

Anak usia dini pengguna gawai tidak bisa sepenuhnya disalahkan, makin pesatnya perkembangan IPTEK (gawai) dewasa ini membawa dampak positif negatif terhadap pertumbuhan bangsa termasuk berpengaruh bagi dunia pendidikan (Semiawan, 2010). Anak-anak yang memasuki usia 2-3 tahun pertama membutuhkan segala macam variasi pengalaman yang merangsang indera. Jika diusia ini anak hanya terpapar penggunaan gawai, maka akan banyak pancaindera yang tidak mendapatkan rangsangan dimasa emas pertumbuhan (golden age). Disamping itu, paparan gawai tanpa batasan dan pendampingan yang baik bukan tidak mungkin akan membuat anak menjadi sangat tergantung pada gawai. Ketergantungan akan gawai diusia yang sangat dini beresiko dapat mengubah perilaku anak yang semula aktif menjadi pasif, anak cenderung suka menyendiri 
atau bahkan menjadi lebih mudah berperilaku agresif (tantrum). Guna mencegah perilaku tersebut semakin meningkat, maka peran orangtua sebagai madrasah pertama anak harus bisa mengembalikan guna gawai kepada fungsinya semula, yaitu sebagai sarana informasi dan komunikasi.

Anak usia kelompok A adalah anak yang berada pada rentanan usia 4-5 tahun pada pendidikan formal RA/TK. UU Sisdiknas (2003) menyatakan, pendidikan anak usia dini adalah pendidikan yang diperuntukkan bagi anak sejak lahir sampai usia 6 tahun. Manusia berkembang melalui beberapa tahapan yang berlangsung secara berurutan, terus menerus dan dalam tempo perkembangan yang tertentu. Menurut Montessori (dalam Sujiono, 2013: 54) mengungkapkan bahwa usia keemasan merupakan masa dimana anak mulai peka untuk menerima berbagai stimulasi dan berbagai upaya pendidikan dari lingkungannya, baik disengaja maupun tidak disengaja. Agar pertumbuhan dan perkembangan anak dapat tumbuh dan berkembang secara optimal, maka orang dewasa harus mampu mengembangkan potensi anak secara maksimal dengan memberikan stimulusstimulus positif yang dibutuhkan oleh anak.

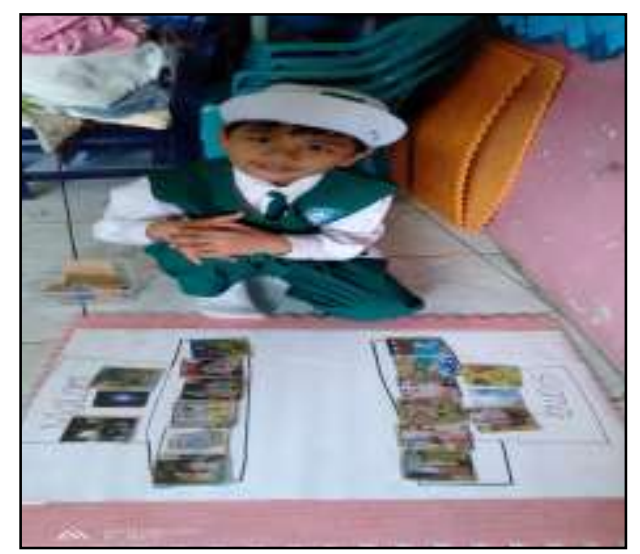

Gambar 1. Anak bermain media bergambar di sentra persiapan

Berdasarkan hasil dokumentasi tersebut, anak belajar sambil bermain dan bermain seraya belajar menggunakan media bergambar di sentra persiapan menunjukkan bahwa peserta didik memiliki antusias yang tinggi dan merasa senang dalam menggunakan media bergambar. Penerapan permainan edukatif media bergambar dalam upaya menjadikan pembelajaran menyenangkan melalui bermain sambil belajar dan belajar seraya bermain serta mengatasi pengaruh penggunaan gawai pada anak usia kelompok A di RA.11 Siti Khadijah Kota Batu dapat dilakukan dengan maksimal.

Secara bertahap dari kegiatan pembelajaran dimasing-masing sentra yang disesuaikan dengan tema pembelajaran menggunakan permainan edukatif berupa 
media bergambar melalui rangsangan dan arahan yang disampaikan Guru kelas dalam suasana pembelajaran yang kondusif adalah sangat baik. Terbukti dengan munculnya beberapa pertanyaan sederhana yang disampaikan peserta didik, interaksi dan tanya jawab sederhana yang terjadi antara peserta didik dengan peserta didik yang lain dan Guru kelas dan penyelesaian masalah belajar peserta didik secara tidak langsung telah membantu seluruh potensi aspek perkembangan peserta didik berkembang optimal. Dari fakta keberhasilan penerapan permainan edukatif berupa media bergambar dalam pembelajaran tersebut, secara tidak langsung kegiatan pembelajaran monoton dan pengaruh penggunaan gawai pada peserta didik di RA.11 Siti Khadijah telah dapat di atasi.

\section{Simpulan}

Berdasarkan hasil temuan data dan pembahasan dalam penelitian ini dapat disimpulkan bahwa penerapan permainan edukatif media bergambar pada anak usia kelompok A RA.11 Siti Khadijah Kota Batu mengalami perubahan proses pembelajaran yang sangat baik. Potensi dalam diri anak berkaitan dengan setiap aspek perkembangan yang dibawa sejak dalam kandungan melalui berbagai rangsangan dan pembiasaan baik harus diberikan kepada anak usia dini. Anak berkembang dan belajar dari lingkungannya dan selalu mengalami perubahan. Adapun faktor-faktor yang mempengaruhi keberhasilan perkembangan seluruh aspek kecerdasan anak usia dini terletak pada orang tua, guru dan lingkungan yang ada disekitar anak.

Melalui penerapan permainan edukatif media bergambar pada anak usia kelompok A, yang dilakukan secara bertahap dengan menyajikan permainan edukatif media bergambar pada kegiatan pembelajaran yang disesuaikan dengan tema pembelajaran di masing-masing sentra, menjadikan pembelajaran berlangsung aktif menyenangkan pada anak usia kelompok A serta meningkatnya seluruh potensi aspek perkembangan peserta didik. Hal ini terbukti dengan adanya peningkatan dan ketuntasan hasil pembelajaran dari ketiga observasi pembelajaran yang dilakukan peneliti dalam kegiatan pembelajaran di masingmasing sentra menunjukkan hasil yang baik. Baik dari segi perkembangan semua aspek kecerdasan peserta didik maupun dari segi penyajian pembelajaran yang menyenangkan bagi anak usia kelompok A melalui inovasi pembelajaran menggunakan media bergambar. 


\section{Daftar Rujukan}

Anderson Jona K. (2010). The Importance of Play in Early Childhood Development. Bozeman: Extension, http://store.msuextension.org/publications/HomeHealthandFamily/MT201003HR.pdf

Dewi, M.S. (2019). Jurnal Pendidikan Islam Anak Usia Dini Volume 1 Nomor 1 Tahun 2019,e-ISSN.

http://riset.unisma.ac.id/index.php/thufuli/article/viewFile/2778/2596

Moeslichatoen. (2004). Metode Pengajaran di Taman Kanak-Kanak. Jakarta: PT RINEKA CIPTA.

Montesori, Maria. Tanpa Tahun. Metode Montesori. Terjemah Gutex, Gerald Lee. 2013. Yogyakarta: Pustaka Pelajar.

Musfiroh, T., \& Tatminingsih, S. (2015). Bermain dan Permainan Anak. Universitas Terbuka

Sadiman, A. (2003: 25). Media Pendidikan dan Syarat media bergambar Jakarta: PT Raja Grafindo Persada.

Santi, D. (2009). Pendidikan Anak Usia Dini Antara Teori dan Praktik. Jakarta: PT Indeks.

Semiawan, C. R (2008). Belajar Dan Pebelajaran Prasekolah Dan Sekolah Dasar. Cet. II.Jakarta: PT Indeks.

Semiawan C. R. (2010). Kreativitas Keberbakatan Mengapa, Apa Dan Bagaimana. Jakarta: PT indeks.

Sujiono, Yuliani Nurani. (2009). Konsep Dasar Pendidikan Anak Usia Dini. Jakarta: PT Indeks.

Sujiono, Y. N. (2013). Konsep Dasar Pendidikan Anak Usia Dini. Jakarta: PT Indeks.

Undang-Undang Republik Indonesia Nomor 20 Tahun 2003 Tentang Sistem Pendidikan Nasional. Tentang pendidikan Anak Usia Dini Usia 0-6 Tahun. Jakarta: Sinar Grafika.

Sulyandari, Ari. (2019). Pengembangan Pembelajaran Mengenal Bilangan melalui Tangga Manik-Manik Montessori di Kelas A TK Anggrek Karangploso Malang http://journal.iaialhikmahtuban.ac.id/index.php/ijecie/article /view/78 3(2)

Sulyandari, Ari. (2017). Representasi Simbol Matematika dalam Proses bermain pada Anak TK. Jurnal Pendidikan: Teori, Penelitian, dan Pengembangan 1 (11)

Wolfinger, Donna M. (1994). Science and Mathematics in Early-Childhood Education. America: Harper Collins College Publisher 